\title{
ОСОБЛИВОСТІ ВЗАЕМОЗВ’ЯЗКУ МІЖ РІВНЕМ САМООЦІНКИ ТА ТИПОМ СТАВЛЕННЯ ДО ХВОРОБИ У ХВОРИХ, ЯКІ ПЕРЕБУВАЮТЬ НА ХРОНІЧНОМУ ГЕМОДІАЛІЗІ
}

\author{
Т. І. Криворучко, О. Б. Сусла \\ Чернігівський діалізний медичний центр «Фрезеніус» \\ ДВНз «Тернопільський державний медичний університет \\ імені І. Я. Горбачевського МОз Украӥни»
}

У статті розглянуто питання про характер змін самооцінки у хворих із термінальною нирковою недостатністю. Показано взаємозв'язок між рівнем самооцінки та типом ставлення до хвороби у хворих, які перебувають на хронічному гемодіалізі.

\section{THE FEATURES OF RELATIONSHIP BETWEEN THE LEVEL OF SELF-CONSEPT AND THE TYPE OF ATTITUDE TO THE DISEASE IN PATIENTS ON CHRONIC HEMODIALYSIS}

\author{
T. I. Kryvoruchko, O. B. Susla \\ Chernihiv Dialysis Centre "Fresenius» \\ I. Horbachevsky Ternopil State Medical University
}

\begin{abstract}
The article discusses the nature of changes in self-concept in patients with terminal renal insufficiency. It reflects the correlation between the level of self-concept and the type of attitude to the disease in patients on chronic hemodialysis.
\end{abstract}

Вступ. Питання про характер змін самооцінки при різних захворюваннях, зокрема у хворих із термінальною нирковою недостатністю (ТНH), на сьогодні досліджені недостатньо.

Г. Н. Носачов, В. С. Баранов, А. Ш. Тхостов, Д. А. Степанович, О. А. Неєлова, С. Ю. Мухтаренко, Т. М. Мураталієва, 3. Т. Саткиналієва, А. В. Добровольський досліджували вплив різних хвороб на самооцінку хворих, емоційний стан особистості, рівень депресії. Більшість досліджень вказує на суттєві зміни в психоемоційному стані хворих, особистісні зміни при тривалому перебігу хвороби. Рівень самооцінки особистості при цьому виступає чинником, який є найбільш чутливим до впливу внутрішніх і зовнішніх факторів, які складають внутрішню картину хвороби, водночас, різко змінюючись під їх впливом так і зумовлюючи їх вплив на особистість хворого [1-5].

Відсутні ґрунтовні дослідження особливостей самооцінки у пацієнтів, які перебувають на хронічному гемодіалізі (ГД), що дає нам підстави до проведення емпіричного дослідження з даної тематики та робить

(ㄱ Т. І. Криворучко, О. Б. Сусла, 2016 його актуальним. Важливим $\epsilon$ з'ясування залежності між періодом перебігу хронічної хвороби нирок (XXH) та рівнем самооцінки особистості пацієнта так само, як ролі статті у формуванні самооцінки у таких пацієнтів.

Основна частина. Метою даної роботи $є$ дослідження особливостей самооцінки та визначення взаємозв'язку між рівнем самооцінки та типом ставлення особистості до хвороби у хворих, які перебувають на хронічному ГД.

Зазначена мета реалізована з використанням методів теоретичного (аналіз, порівняння, узагальнення) та емпіричного (методи первинної та вторинної математико-статистичної обробки) дослідження.

Обробку та аналіз отриманих результатів здійснювали за допомогою програми IBM SPSS Statistics Version 21.

Вибірку дослідження склали 79 хворих на термінальну ниркову недостатність, які перебувають на програмному гемодіалізі. Для осіб, які брали участь у дослідженні характерні такі соціально-демографічні характеристики. Серед них 39 чоловіків та 40 жінок 
віком від 30 до 65 років. 48 осіб мають повну вищу освіту (60,8 \% опитаних), 24 (30,4 \%) - середню спеціальну, 5 (6,3 \%) - незакінчену вищу, 2 (2,5 \%) середню освіту. В офіційному шлюбі перебували 49 (62,0 \%) хворих, 14 (17,7 \%) - розлучені, 9 (11,4\%) проживають у громадянському шлюбі, 7 (8,9%) - не одружені. Респондентам запропонували відповісти на питання анкети і вказати приблизний період перебігу хвороби (загальний період перебігу хвороби з врахуванням перебування на ГДлікуванні). Показники за період перебігу хвороби розподілилися таким чином: 24 особи (30,4 \%) хворіли менше 1-го року; 18 (22,8 \%) - від 1-го до 3-х років; 5 (6,3 \%) - від 3-х до 5-ти; 15 (19 \%) - від 5-ти до 10-ти; 14 (17,7 \%) - від 10-ти до 15-ти років; понад 15 років хворіють 3-є пацієнтів (3,8\%).

3 метою виявлення рівня самооцінки було проведено тестування за методикою С. А. Будассі. Отримано такі результати: 53 пацієнти (67,0 \% опитаних) мають неадекватну, занижену самооцінку. Їм властиве порушення саморегуляції, самоконтролю, підвищена конфліктність через надмірну критичність. Вони дуже вимогливі до себе і ще більш вимогливі до інших, не вибачають жодного свого промаху чи помилки, схильні постійно підкреслювати недоліки інших, що стає причиною конфліктів у силу того, що небагато хто може терпіти систематичне «знущання». Коли в тобі бачать лише погане і постійно вказують на це, то виникає ворожість до джерела таких оцінок, думок і дій.

Завищена, неадекватна самооцінка властива 12 особам (15,2%). Для даної групи респондентів теж була характерна підвищена конфліктність, порушення саморегуляції, самоконтролю. Конфлікти виникають через зневажливе ставлення до інших людей, занадто різкі та необґрунтовані висловлення на їх адресу, нетерпимість до чужої думки, прояви зарозумілості й зазнайкуватості. Низька критичність до себе заважає їм навіть помітити, як вони ображають інших зарозумілістю і незаперечністю суджень.

Лише у 14 (17,75 \%) ГДхворих визначали адекватну самооцінку.

Таким чином, більше ніж 82 \% обстежених мали неадекватну самооцінку, у 67 \% самооцінка занижена.

Серед чоловіків та жінок показники самооцінки розподілилися таким чином (табл. 1).

Таблиця 1. Особливості рівня самооцінки у чоловіків та жінок, які перебувають на хронічному ГД

\begin{tabular}{|c|c|c|c|c|}
\hline \multirow{3}{*}{ Рівень самооцінки } & \multicolumn{4}{|c|}{ Стать } \\
\hline & \multicolumn{2}{|c|}{ чоловіча } & \multicolumn{2}{|c|}{ жіноча } \\
\hline & $\mathrm{n}$ & $\%$ & $\mathrm{n}$ & $\%$ \\
\hline Неадекватна, занижена & 27 & 69,2 & 26 & 65,0 \\
\hline Адекватна & 8 & 20,5 & 6 & 15,0 \\
\hline Завищена, неадекватна & 4 & 10,3 & 8 & 20,0 \\
\hline Загалом & 39 & 100,0 & 40 & 100,0 \\
\hline
\end{tabular}

Отже, у відсотковому відношенні загальна кількість осіб із заниженою самооцінкою приблизно однакова (65\% у жінок та $69 \%$ у чоловіків).

Варто зазначити, що жінок, які мають завищену самооцінку, в процентному відношенні більше, ніж чоловіків (20 \% проти 10,3 \%). Можливо, це пояснюється тим, що жінки більш емоційно реагують на перебіг хвороби, більш схильні до невротичних реакцій, намагаючись знайти вихід з несприятливої емоційної ситуації у спілкуванні, яке має водночас і конфліктний характер, відтак - виступає своєрідним захисним механізмом.

Особливості розподілу рівня самооцінки залежно від тривалості хвороби наведено в таблиці 2. Суттєвих відмінностей між показниками рівня самооцінки та періодом перебігу хронічної хвороби нирок немає.
Зберігається відносна постійність, у відсотковому відношенні, кількості хворих, які мають різні рівні самооцінки незалежно від тривалості захворювання. Так, наприклад, неадекватну занижену самооцінку мають 66,7 \% осіб, які хворіють менше року, від 1 до 3 років, від 5 до 10 років.

3 метою виявлення взаємозв'язків між рівнем самооцінки та ставленням до хвороби нами проведено процедуру кореляційного аналізу (з використанням коефіцієнта лінійної кореляції Пірсона). Встановлено такі статистично значущі взаємозв'язки.

Отримано позитивний кореляційний зв'язок між рівнем самооцінки та егоцентричним (істероїдним) ставленням до хвороби ( $r=0,27$ при $p \leq 0,01)$. Тобто, чим вищий рівень самооцінки, тим більш властиве хворим виставляння напоказ близьким і оточуючим 
Таблиця 2. Особливості рівня самооцінки залежно від тривалості хронічної хвороби нирок

\begin{tabular}{|c|c|c|c|c|c|c|c|c|c|c|c|c|}
\hline \multirow{3}{*}{$\begin{array}{c}\text { Рівень } \\
\text { самооцінки }\end{array}$} & \multicolumn{12}{|c|}{ Тривалість хвороби } \\
\hline & \multicolumn{2}{|c|}{ до 1 року } & \multicolumn{2}{|c|}{$\begin{array}{l}\text { від } 1 \text { до } 3 \\
\text { років }\end{array}$} & \multicolumn{2}{|c|}{$\begin{array}{c}\text { від } 3 \text { до } 5 \\
\text { років }\end{array}$} & \multicolumn{2}{|c|}{$\begin{array}{c}\text { від } 5 \text { до } 10 \\
\text { років }\end{array}$} & \multicolumn{2}{|c|}{$\begin{array}{c}\text { від } 10 \text { до } 15 \\
\text { років }\end{array}$} & \multicolumn{2}{|c|}{$\begin{array}{c}\text { понад } 15 \\
\text { років }\end{array}$} \\
\hline & $\mathrm{n}$ & $\%$ & $\mathrm{n}$ & $\%$ & $\mathrm{n}$ & $\%$ & $\mathrm{n}$ & $\%$ & $\mathrm{n}$ & $\%$ & $n$ & $\%$ \\
\hline $\begin{array}{l}\text { Неадекватна, } \\
\text { занижена }\end{array}$ & 16 & 66,7 & 12 & 66,7 & 3 & 60,0 & 10 & 66,7 & 11 & 78,6 & 1 & 33,3 \\
\hline Адекватна & 5 & 20,8 & 2 & 11,1 & 1 & 20,0 & 4 & 26,7 & 1 & 7,1 & 1 & 33,3 \\
\hline $\begin{array}{l}\text { Неадекватна, } \\
\text { завищена }\end{array}$ & 3 & 12,5 & 4 & 22,3 & 1 & 20,0 & 1 & 6,7 & 2 & 14,3 & 1 & 33,3 \\
\hline Загалом & 24 & 100,0 & 18 & 100,0 & 5 & 100,0 & 15 & 100,0 & 14 & 100,0 & 3 & 100,0 \\
\hline
\end{tabular}

своїх страждань і переживань для того, щоб викликати співчуття і повністю заволодіти їхньою увагою, вимога виняткової турботи про себе на шкоду іншим справам і турботам, повна неуважність до близьких. Розмови оточуючих швидко переводяться «на себе». Інші люди, які також вимагають уваги і турботи, розглядаються як «конкуренти», ставлення до них неприязне. Постійне бажання показати іншим свою винятковість відносно хвороби, несхожість на інших. Емоційна нестабільність і непрогностичність.

Отримано деякі взаємозв'язки між різними типами ставлення до хвороби. Так, позитивні кореляційні зв'язки наявні:

- між гармонійним та ергопатичним типами ставлення до хвороби ( $r=0,55$ при $p \leq 0,01)$. Вочевидь, оцінка свого стану без схильності перебільшувати його тяжкість, прагнення у всьому активно сприяти успіху лікування, прагнення полегшити близьким труднощі догляду за собою, поєднується з прагненням, незважаючи на тяжкість захворювання, продовжувати роботу, з бажанням будь-що зберегти професійний статус і можливість продовження активної трудової діяльності. Можливо останнє виступає своєрідним захисним механізмом, який дозволяє адекватно оцінювати свої соціальні можливості й протидіяти хворобі;

- між гармонійним та сенситивним типами ставлення до хвороби ( $r=0,41$ при $p \leq 0,01)$. Таким чином, чим більш виражені в поведінці ознаки гармонійного типу, тим більш властива надмірна вразливість, заклопотаність можливими несприятливими враженнями, які можуть справити на оточуючих відомості про хворобу, острах стати тягарем для близьких через хворобу;

- між ергопатичним та сенситивним ( $r=0,24$ при $\mathrm{p} \leq 0,01)$. Імовірно, незважаючи на тяжкість захворювання, прагнення продовжувати роботу, будь-що зберегти свій професійний статус і можливість продовження активної трудової діяльності, поєднуються 3 надмірною вразливістю, заклопотаністю можливими несприятливими враженнями, які можуть справити на оточуючих відомості про хворобу;

- між ергопатичним та дисфорічним ( $r=0,37$ при $\mathrm{p} \leq 0,05)$. Чим більше прагнення продовжувати роботу, будь-що зберегти свій професійний статус, тим більш властивим $€$ похмурий настрій, постійний невдоволений вигляд, заздрість і ненависть до здорових людей, включаючи рідних і близьких, агресивне, деспотичне ставлення до близьких, вимога у всьому догоджати.

Наявні кореляційні взаємозв'язки між гармонійним та сенситивним типами, ергопатичним та сенситивним, ергопатичним та дисфорічним характеризуються наявністю суттєвих протиріч у поведінці пацієнта, його ставленні до себе та оточуючих, що дає нам право припустити можливість наявності тривалого внутрішньоособистісного конфлікту в пацієнтів із ТНН, для яких характерні поєднання подібних типів ставлення до хвороби, що, в свою чергу, негативно впливає на перебіг лікування та може призводити до невротичних розладів.

Негативні кореляційні взаємозв'язки отримано між:

- між гармонійним та іпохондричним ( $r=-0,23$ при $\mathrm{p} \leq 0,05)$. Чим більше виражені в поведінці ознаки гармонійного типу, тим менш властиве надмірне зосередження на суб'єктивних хворобливих та інших неприємних відчуттях, прагнення постійно розповідати про них лікарям, медперсоналу Гд центру і оточуючим, а також перебільшення неприємних відчуттів у зв'язку з діалізним лікуванням, побічними діями ліків і діагностичних процедур;

- між анозогнозичним та паранояльним ( $r=-0,25$ при $\mathrm{p} \leq 0,05)$. Чим більше виражений анозогнозичний тип (пацієнту властиве активне відкидання думок про хворобу, про можливі її наслідки, виражені тенденції розглядати симптоми хвороби як прояви «несерйозних» захворювань або випадкових коливань самопочуття), тим менш властива впевненість, що хвороба - 
результат зовнішніх причин, чийогось злого наміру, прагнення приписувати можливі ускладнення лікування, побічні дії ліків недбалості або злому наміру лікарів і персоналу.

Висновки. Аналіз результатів, отриманих у ході емпіричного дослідження у хворих, які перебувають на хронічному ГД, дозволяє зробити такі висновки:

1. Більшість пацієнтів має завищену або занижену неадекватну самооцінку.

2. Для жінок більш характерна завищена самооцінка.

\section{ЛІТЕРАТУРА}

1. Носачёв Г. Н. Семиотика психических заболеваний (общая психопатология) [Электронный ресурс] / Г. Н. Носачёв, В. С. Баранов. - Режим доступа: http://www. studfiles.ru/preview/398799/page:4/

2. Молчанова О. Н. Самооценка: теоретические проблемы и эмпирические исследования / О. Н. Молчанова. М. : Флинта; Наука, 2010. - 392 с.

3. Мухтаренко С. Ю. Влияние особенностей восприятия болезни на качество жизни у больних коронарной болезнью сердца, осложнённой сердечной недостаточностью [Электронный ресурс] / С. Ю. Мухтаренко, Т. М. Мурата-
3. Отримано позитивні кореляційні взаємозв'язки між рівнем самооцінки та егоцентричним (істероїдним) ставленням до хвороби, між гармонійним та ергопатичним типами ставлення до хвороби, між гармонійним та сенситивним типами ставлення до хвороби, між ергопатичним та сенситивним, між ергопатичним та дисфорічним.

4. Отримано негативні кореляційні взаємозв'язки між гармонійним та іпохондричним ставленням до хвороби, між анозогнозичним та паранояльним ставленням до хвороби.

лиев, 3. Т. Саткыналиева. - Режим доступа : http://arch. kyrlibnet.kg/uploads/KRSUMUHTARENKOS.U.2003-7.pdf

4. Мысливцева А. В.Исследованиепсихоэмоционального состояния больных с урологической патологией [Электронный ресурс] / А. В. Мысливцева, А. Н. Золотова, Д. А. Золотухин. - Режим доступа: http://www.rostov2013. nc-i.ru/

5. Неелова Е. А. Психологические методы исследования депрессивных состояний [Электронный ресурс] / Е. А. Неелова. - Режим доступа : http://stelmash.ru/ psixologicheskie-metody-issledovaniya-depressivnyxsostoyanij/ 